\title{
The Crucifix in State Schools in Italy, Victim of Globalization, between Freedom of Religion and Freedom of Education
}

\author{
Dr. Renata Tokrri \\ Vice-Rector, Lecturer, \\ University "Aleksandër Moisiu", \\ 14, 2001, Rruga Currila, Durrës, Albania
}

DOI: https://doi.org/10.36941/jesr-2021-0o61

\begin{abstract}
The interest to analyse the phenomenon of the exposure of religious symbols, particularly of the crucifix, in state schools in Italy and the principle of secularism, derives from the cultural and constitutional peculiarities that this system presents, as a consequence of the historical and cultural events that have influenced its ordering. First of all, it must be pointed out, as indeed it is evident, that Catholicism was the dominant faith for about two thousand years, and until recently, almost the only one. The Catholic religion has crossed the entire history of the country, penetrating and intertwining with the socio-cultural dynamics. For this reason, the Italian constitutional history has been crossed by the principle of tolerance. The latter can be considered clearly out-dated only with the Republican Constitution of 1948, thus the legal system emptied itself of its confessionalism. The last few years, as a result of strong migratory flows, the religious-cultural landscape, not only in Italy, but throughout Europe it seems to have changed. Other cultures have brought their own customs, languages and religions like a wave. Thus we are witnessing an extraordinary social, economic and juridical transformation. In this multicultural mosaic, the clash between civilizations could not be missing. Minorities have in many cases felt they were discriminated against, bullied and offended by the display in public buildings (schools, courtrooms, hospitals, etc.) of the symbol par excellence of Christianity, namely the crucifix, arousing the protest of parents of different faiths. All this has produced legal conflicts and jurisprudential rulings that have involved the European Court of Human Rights itself. This discussion aims to analyze from a socio-juridical point of view, the consequences of religious symbology external to educational institutions and to be able to give a juridical truth, stripped of religious indoctrination. This path will not be easy since every element inherent to religion touches delicate aspects, linked in particular with what is most profound in the people and culture of a country.
\end{abstract}

Keywords: Religious symbols in state schools, principle of the secular State, freedom of religion, multi-religious society

\section{Introduction}

As for the exhibition of religious symbols in school classrooms in Italy, the crucifix has been the most debated symbol. It is indisputable that he is the symbol par excellence of the Christian religion, and represents for the latter a point of reference, where the global vision of Christianity is crystallized.

The crucifix is the key to reading the Bible, we can define it as a hermeneutic symbol of the Bible.

His message of sacrifice is clear, it is true, of a historical reality that really happened. In this perspective, the exhortation that Pope Francis, in 2018, addressed to the faithful appears very 
interesting, expressing to teach children to look at the crucifix as it is "the key to our salvation, the key to our patience on the journey of life, the key to overcoming our deserts".

It is noted that, if the crucifix is the symbol par excellence of Christianity, Christianity is the faith par excellence of Italy, where this religion has taken root in the collective fabric and has profoundly marked the essence of civilization, culture and the history of Country. Consequently, a particular relationship arises between the State, the Church and society. (Hobbes, 2004)

The panorama of the collective fabric not only in Italy, but throughout Europe seems to have changed as an effect of the strong migratory flows that have brought their own cultures, customs, languages and religions like a wave on Europe, thus witnessing an extraordinary social, economic and legal transformation. Judges have often found themselves faced with unexpected constitutional challenges, and the law has not infrequently traveled stories linked to peaceful coexistence between different religions.

Today Italy and the United Europe ${ }^{1}$ are multicultural, this is a matter that law and jurists cannot ignore since multiculturalism needs constitutional guarantees in order to be able to keep the essential features of integration intact.

To be functional, the Constitution must stand above every culture, every creed, it must stand as a beacon that illuminates multiculturalism. Consequently, according to the constitutionally guaranteed principles, that is, the principle of equality and pluralism, all cultures deserve equal value and respect.

Multiculturalism implies a fusion of civilizations (Huntington, 2000). The result is a mosaic and hybrid society, where the majority culture is not the only truth, it is no longer identifiable and distinguishable. This is the core of our problem.

It is true that the constitution was created by a country, by a people to adapt it to their own culture, but the Constitution is not nihilistic, and an end in itself, but is capable of surviving the challenges of the times and the evolution of societies. We can define multiculturalism as an evolution and consequence of globalization. (See Bauman, 2008; Beck, 1999; Castells, 2004; Clark, 1997; Giddens, 2000; Hirst, Thompson, 1999; Huntington, 1998; Huntington, Berger, Peter, 2002). But the multiculturalism is also the consequence of a worldwide disparity of common goods (See Gallino, 2003; Cornia, 2012; Olinto, Saavedra, 2012; Feng, 2011; Bourdieu, 2001; Bauma, 1999). In these latter terms, advanced societies, which benefit to a greater extent from earthly resources, must commit to welcoming and giving the possibility of integration into their own culture.

This process, from a legal point of view, can only take place vertically, through the principle of equality and non-discrimination, that is, through a correct interpretation of the constitutional principles. A correct interpretation of these principles can also give a "right globalization". (Ricciardi, 2020)

\section{Literature Review}

To properly analyze the problem of religious symbolism in public schools in Italy, in particular the

\footnotetext{
${ }^{1}$ Regarding, the protection of freedom of religion in the Charter of Fundamental Rights of the EU is recognized in Article 10, which means that the European Union formally recognizes this right. Despite this provision in the Charter, the European institutions have not directed competence in religious question since according to Article 5 part 1 TEU, delimits the competences of the EU according to the principles of attribution, subsidiarity and proportionality. In other words, the Union acts within the limits of these principles. Also Article 17 TFEU imposes a legal obligation not to prejudice the status that churches enjoy in the Member States by virtue of national law, recognizing their identity and specific contribution. Despite this, the judges of the Court of Justice can exercise their jurisdiction in guarantee of the freedom of religion provided for in Article 10 of the EU Charter of Fundamental Rights. Although the EU does not have direct jurisdiction in the matter, its Court can affect the law of the member states on certain issues and in particular on the display of religious symbols in public buildings.
} 
crucifix, we must start from the etymology, both of the word "symbol", and of "crucifix".

"Symbol" derives from the ancient Greek ( $\sigma u ́ \mu \beta o \lambda o v$, symbolon) and means to put together two distinct parts. In particular, when two families separated, they split a plate in half, and each took a share.

This rite had the purpose that, when the descendants met after a long time, they could put the parts together and thus recognize each other. Each of the two families carried one half of the truth. Each half became a symbol and acquired meaning only by uniting. Here a broken plate became a symbol of a family, of a blood, of a truth.

Rather, the word "cross" derives from the Latin crux, and represents one of the most remote symbols of humanity, and among the ancients it mainly indicates a pen tool. The cross takes on religious significance for Catholics, with the crucifixion of Jesus (Encyclopedia Britannica), becoming a symbol of God's love. The cross unites the faithful, but at the same time it has become an ethnoidentity symbol in which different nations, peoples and ethnic groups are identified. It is believed that the more this symbol penetrates into the culture, the more theological contents are lost, but at the same time the ethnic and identity claims grow. (Rusconi, 2003)

Hence the reason that every time someone asks to tear the cross from the walls of the schools, the question leads to an open public debate. The modern jurist cannot ignore this situation, which more than any other causes discussion on the principle of the secular state.

On the subject, the doctrine has been divided in half, one part believes that the crucifix is a cultural and identity symbol, and should not be removed from public schools in Italy. (Cardia, 2010)

The other part invites to elaborate a secular ethics and not to impose one's own truth, as democracy is relativist and cannot coexist with absolutism. (Zagrebelsky, 2010)

Part of the doctrine proposed a solution of maximum inclusion of all religious confessions, suggesting the posting in state schools of all religious symbols, in a sort of Pantheon of the faiths professed by associates and pupils. (Chessa, 2006) ${ }^{2}$

This view has been criticized by others, not only because the so-called negative freedom, i.e. atheism, and due to the fact that some religions are devoid of symbols, but also because, from an objective point of view, it appears not possible. (Rimoli, 1995)

Some time ago, the Minister of Education expressed that the crucifix in classrooms can be replaced with a map. This request was rejected by almost all parties and others accused him of cultural ignorance. This declaration gave rise to anew the public debate between the laity and the clerical. Thus the history of the crucifix is a cyclical repetition of events.

The literature proposed to develop the topic is of a narrative type and aims to compare different ideas. Also, at the center of the analysis will be the interpretations of the decisions of the Courts of Nations and the European Court of Human Rights, the latter having consequently assumed an important role in the matter of religious symbolism exhibited in public schools, dictating new principles for all the Contracting States.

\section{Research Method}

This work is essentially an immersion in the decisions of the national courts and the ECHR. Hence the reason that this study is conceptually divided into two parts: the first examines the decisions of the TAR of Veneto and the Council of State, the second focuses on the analysis of the decisions of the European Court of Human Rights. These passages of interpretation from the various courts help us to

\footnotetext{
${ }^{2}$ The A. argues that secularism "as equal respect and consideration is instead the perspective that welcomes all the others; it is the greatest understanding of the highest possible number of particular positions; it is the same pluralism that becomes the norm, thanks to the principle that all the perspectives of life must be equally respected. Each of us has the right to demand that their conception of the good life be treated with equal respect and consideration compared to all the others, not the right to inhibit the expression of others".
} 
better understand the formula of freedom of religion and the model of secularism envisaged in the new 1998.

At the same time, the intent of the analysis aims to understand how a particular culture deals with the problem of religious symbolism in schools from a juridical-constitutional point of view, in a moment where globalization has contaminated Italian culture, and multi-religiosity changed society.

The method followed is the historical-legal one, used with the aim of understanding what repercussions the evolution or metamorphosis of society has had on freedom of religion. Furthermore, it is essential to divide the principle of secularism and religious pluralism from the political and sociological elements, so it was impossible not to use their criteria to project the cardinal principle of the secular state into the future.

\section{The Crucifix in School Classrooms in Italy}

As for Italy, it is evident that the Catholic religion has always been the majority faith and has taken root in the country as a primary socio-cultural element even for the laity and non-believers. (Cf. Jemolo, $1961)^{3}$

Hence the reason why the fundamental Charter (articles 3.7, 8, 19, 20 of the Constitution) provides not only for the protection of religious freedom, but also for specific and in some way privileged relationships between the State and the Catholic Church. (Grossi, 2008; Mateucci, 1996; Bobbio, 1990)

For this reason, the Italian constitutional history has been crossed by the principle of tolerance, because the Catholic religion has been recognized as the one and only state religion. According to Grossi (2008, p.107), however, the other cults were only tolerated. (See Tokrri 2015; Tokrri, 2020)

Only with the Republican Constitution of 1948, the previous positions of simple tolerance can be clearly considered out-dated and in this way the legal system was emptied of its confessionalism. (Tokrri, 2017)

The reality of multiculturalism requires that we return to reflect on the theme of the secular state. (Valentino, 2014; Abet, 2005, pp. 157 e ss; Risset, 2005, pp. 167 e ss; Riviera, 2005, pp. 171 e ss; Semplici, 2005, pp. 191 e ss; Baldassare, 2004, p. 263; Martinelli, 2007)

This principle is not provided for in the Italian Constitution, but has been extrapolated from the joint reading of Articles 2, 3, 7, 8, 19 and 20 of the Constitution. Now, it is precisely from the set of provisions just mentioned that the Constitutional Court intended to derive the principle of secularism by defining it as "one of the profiles of the form of State outlined by the Constitutional Charter of the Republic". (Majorana, 2004, p. 195; Conte, 2005, pp. 1137-1151)

Thus the constitutional jurisprudence affirmed for the first time the principle of the secular state with the sentence n. 203 of 1989.

As for the exposition of the crucifix in state schools in Italy, was arranged in a circular in 1857 , when the Catholic was the state religion. It was definitively introduced into the classrooms of schools with the issue C. M. P. I. 22 of 1922, n. 68, and, with a subsequent circular of 1923, n. 8823. (Cf. Telemanca, 1975, pp. 236-237; Zannotti, 1990, p. 223).

In 2004 Ms. Lautsi, in light of the principle of secularism, appealed to the TAR of Veneto, with the reason that the display of the crucifix in the classrooms frequented by her children represented a limitation of religious freedom. The TAR of Veneto has consulted the Constitutional Court, raising the question of the constitutionality of articles 159 and 190 of the legislative decree 16 April 1994, n. 297 (Consolidated text of the provisions in force on education, relating to schools of all types and levels). The Constitutional Court simply declared itself unsuitable to discuss the case, as these provisions did

3 The A. notes that, not surprisingly, freedom of religion was constitutionally recognized before other freedoms, even in the ancient world it was the first to be claimed. (p. 131) 
not have the force of law ${ }^{4}$. At this point, the TAR of Veneto in 2005 rejected the appeal, expressing that the crucifix in the classrooms does not infringe the principle of the secular state, but is a symbol of Italian culture and history, a symbol of national identity. (See Colaianni, 2010).

Mrs Lautsi, convinced she was right, turned to the Council of State in 2006. In February 2006, the Council of State (VI) confirmed the first instance sentence and ruled in favor of the presence of the crucifix ${ }^{5}$. It believes that the Constitution shows an attitude of favor religionis, and that in Italy, the crucifix symbolically expresses the religious origin of the values of tolerance (Tokrri, 2015). The Council of State also recognized in the crucifix a secular value of the Italian Constitution, representative of civil values.

According to the Council of State, the crucifix can take on different meanings and serve different purposes, first of all for the place where it is placed, consequently for the Court in the schools this symbol represents civilly relevant values, values that inspire the constitutional order and which are at the foundation of civil co-living. (See Celotto, 2004, pp. 95 e ss; Colaianni, 2004, p. 1; Fiorita, 2005; Veronesi, 2005, pp. 678 e ss; Fusaro, 2004, 150; De Oto, 200o, pp. 837 e ss; Majorana, 2004, pp. 199-200)

In this sense, the crucifix can perform a highly educational symbolic function, regardless of the religion professed by the pupils ${ }^{6}$.

Given the foregoing, in the opinion of the Council of State, the display of the crucifix not only cannot be considered harmful to the freedom of conscience of the pupils and teachers of public schools, but has an educational function from the point of view of civil coexistence. (See Luciani , 2008, pp. 105133; Olivetti, 2001; Vari, 2012, pp. 3-4-12; Cimbalo, 1999; Vari, 2012, pp. 3-4-12; Tokrri, 2019)

\section{The Crucifix in Strasbourg (First Instance)}

In 2006 the Strasbourg judges are questioned following the appeal of Ms Lautsi who turned to the ECHR after having unsuccessfully denounced before the National Court (See Tokrri, 2014). Lautsi contested the alleged violation of the freedom of conscience, thought, religion and the right to education, since Article 2 of Protocol No. 1 expresses that "the State in the exercise of the functions it assumes in the field of education and teaching, must respect the right of parents to provide such education and teaching according to their religious and philosophical convictions".

In the sentence of November 3, 2009, the ECHR found that there was a violation of Article 2 of Protocol No. 1 examined jointly with Article 9 of the Convention, and condemned the Italian

\footnotetext{
${ }^{4}$ Thus the Constitutional Court, ordinance no. 389 of 2004. In particular, the Court expresses that "the challenge of the aforementioned provisions of the consolidated act therefore appears to be the result of an improper transfer to legislative provisions of a question of legitimacy concerning the aforementioned regulatory norms: norms lacking the force of law, on which a review of constitutional legitimacy cannot be invoked, nor, consequently, an interpretative intervention by this Court"

${ }^{5}$ The Council of State ruled in favor of the presence of the crucifix, both with Opinion no. 63 of 1988, of 1988 and with the more recent 2006 of Mrs. Lautsi.

${ }^{6}$ It is on the basis of these premises that the Council of State affirmed that: a) "It is evident that the crucifix is itself a symbol that can take on different meanings and serve different purposes; first of all for the place where it is placed". $b$ ) "In a place of worship, the crucifix is properly and exclusively a "religious symbol", as it aims to solicit reverent adherence to the founder of the Christian religion"; c) instead, "in a non-religious setting, such as a school, intended for the education of young people, the crucifix will still be able to hold the aforementioned religious values for believers, but for believers and non-believers its exposition will be justified and will take on a meaning non-discriminatory from a religious point of view, if it is able to represent and recall in a synthetic form immediately perceptible and intuitive (like any symbol) civilly relevant values, and in particular those values that underlie and inspire our constitutional order, the foundation of our civil co-living. In this sense, the crucifix will also be able to play a highly educational symbolic function, regardless of the religion professed by the pupils, even in a "secular" horizon, different from the religious one that belongs to it". Thus the Council of State, sentence no. 556 of February 13, 2006, Section VI., in Quaderni di diritto e politica ecclesiastica, 2006.
} 
government to pay her a compensation of 5,00o.oo euros for moral damages. (Cf. Fiorillo, 2010, pp. 145 e ss; D’Elia, 2012, p. 7; Belgiorno De Stefano, 2010; Laudani, 2010; Cortese, Mirate, 2010; Carlassarre, 2019, pp. 554 e ss; Busnelli, 2009, pp. 549 e ss; Kermiche, 2009; Ruggiu, 2010; Dickman, 2010; Andò, 2009; Genio, 2009; Denaro, 2009)

In this historic ruling, the only one that "tears" the crucifix from the walls of state schools in the country, the ECHR believes that the crucifix can have multiple meanings but without doubt the religious meaning is predominant. Consequently, he observed that the obligatory and ostentatious presence of the crucifix in the classrooms was such, not only as to offend secular beliefs, but also to emotionally upset the pupils who professed a religion other than Christian or did not profess any religion. The protection of the latter is also taken into consideration.

The Chamber highlights that in the case in which the State "identifies" itself with a particular religion, then the freedom of religion deserves even more particular protection, since citizens are in a position to passively submit to the majority faith and not they can free themselves except with effort and sacrifice. In other words, in a state with weak secularism, religious freedom must be strengthened.

For the Chamber, the State is bound to confessional neutrality in education, in these terms neutrality does not only imply the lack of religious services or religious teachings, but extends to all religious practices and symbols, in particular than in general. The European Convention on Human Rights conceives society as a "democratic society" and to be able to create or preserve such an idea of society, the way passes through education.

For this reason, public schools must try to infuse in students the habit of critical thinking, and the crucifix, as a religious symbol of the majority religion, would not serve educational pluralism. The Court conceives educational pluralism ad includendum and not ad scludendum, that is, a school environment that encourages inclusion regardless of religious or ethnic origins.

In the vision of the school as a meeting place between different philosophies and traditions, a single symbol can exert pressure on the freedom of students, especially if they are of formative age. The setting of a single truth can make the school a place of confrontation.

The Court also maintains that "the crucifix displayed in public schools is a pre-eminently religious value, typical of the Catholic religion prevalent in Italy, and, therefore, capable of undermining the negative freedom of not being able to adhere to any religion, as well as in contrast with pluralism religious".

From here, the European judges deduce that "the compulsory display of a symbol of a specific religious confession in schools is in contrast with the right of parents to educate their children according to their own religious and philosophical convictions as well as with the right of everyone to believe or not to believe, since in the exercise of a public function (such as public education) the State should have maintained an attitude of neutrality". At the basis of these considerations, as already mentioned, the violation of art. 2 of Protocol No. 1 in conjunction with Article 9 of the Convention.

\section{The Crucifix in Strasbourg (Second Instance)}

The Italian representation decided to appeal to the Grand Chamber in the second instance, the ECHR in second instance, overturns the previous judgment.

The decision of the Grand Chamber relies on three fundamental arguments: the passive character of the religious symbol; the margin of appreciation enjoyed by the States in the matter; the pluralistic nature of the public school in Italy. Taken together, each of these arguments marks a turning point in the Court's jurisprudence. (Cavana, 2012; Ventura, 2012, pp. 293-362).

In other words, the mere posting of the crucifix in school classrooms if it is not accompanied by compulsory teaching of religion cannot indoctrinate the Christian religion, consequently it does not violate the right of parents to guide their children towards an education that conforms to their religious 
convictions ${ }^{7}$.

If in the first instance, the ECHR considers the crucifix as an essentially strong symbol, in the second instance it is qualified as a weak symbol. In these latter terms, a weak symbol whose simple exposure would not constitute a mere passivity as there would be no objectives of proselytism or conditioning of consciences in it (See Ferrari, 2001, pp. 9 et seq; Tokrri, 2019), for this reason, its impact on pupils and parents is irrelevant and they could not consider themselves harmed in their legal sphere by the mere presence of a religious symbol corresponding to the traditions of the country.

The crucifix is compared to a cultural symbol that has marked the evolution, the destiny, the formation of a social and anthropological identity and consequently the majority of the community is recognized in it, compared to the display of the national flag or other resulting symbologies from the historical context.

The Court argues that a passive symbol cannot propagate, influence and indoctrinate pupils.

According to some scholars, this interpretation would lead to the trivialization of the symbol emptied of any content or meaning. (Zagrebelsky, 2012, pp. 32-33; Gattamorta, 2016; Turdov, 1991) ${ }^{8}$

It is noted that for the ECHR, the passivity of the symbol is a guarantee for observing above all the principle of neutrality (ECHR, Grande Chambre, Lautsi v. Italy). But the passive character of the symbol can be related from an aesthetic point of view but not to its meaning, which remains that acquired in the social context of reference - "le crucifix est avant tout un symbole religieux".

The second argument used by the Grand Chamber is the principle of the margin of appreciation, which recognizes that the Contracting States enjoy a certain discretion in administering the school and educational service in the interest of the community and in assessing its impact with individual beliefs and with the right of parents to orient their children towards philosophical and religious tendencies of preference.

Ultimately, the decision to preserve or not a tradition falls within the principle of the margin of appreciation of each Member State, also taking into account that "Europe is characterized by great diversity among the member countries that make it up, also in terms of historical evolution and cultural even if evoking a tradition does not exempt the Contracting State from the obligation to respect the rights and freedoms enshrined in the Convention".(ECHR, Grande Chambre, Lautsi v. Italy).

The third topic where the Grand Chamber dwells is the principle of pluralism. A conciliatory pluralism, since it is stated that the Italian State opens school spaces to other religions by observing how the use of the Islamic veil or other symbols is not prohibited in the school and how conciliation with other faiths is sought (ECHR, Grande Chambre, Lautsi v. Italy).

\section{Collective Identity Victim of Globalization}

Even today in the XXI-th century, when everything seems to move from economic and financial utility, the human being in front of the beauty of the Universe, and the mystery of life, cannot be indifferent, which is why the search for the transcendent it is something necessary, a point of reference, in order not to leave the spirit in the void of natural uselessness to which each of us is destined.

For many years, not only Italy but all of Europe has been dealing with the phenomenon of globalization, the strong migratory flows to Europe from Islamic countries, but not only, have introduced new geopolitical dimensions into this and different professions of faith without, however, affecting the connective tissue of not only religious but also cultural beliefs of the indigenous

\footnotetext{
${ }^{7}$ Cause Lautsi and others v. Italy, Grande Chambre, judgment of 18 March 2011 (appeal no. 30814/o6).

${ }^{8}$ In particular, according to Zagrebelsky, "Passive symbol represents an oxymoron to be understood as a mute symbol, which says nothing of its own, which has lost its soul, because anyone can make it say what they want, as if it were a puppet. (...) After having been so secularized, laicized, sociologized, in order to be able to hang it in the classrooms of schools and courts, it has even been silenced: a mute symbol that symbolizes nothing, and therefore "harmless" because it is dead". (pp. 32-33)
} 
population.

All this has forced individual nation states to face the problem of coexistence between different religions and effective freedom in the exercise of their confession on the ground.

Often religion and culture are the same thing, this means that the integration process does not lead to social conflicts, a need for acceptance, acceptance but also for adaptation. That is, it needs both stakeholders of the interests at stake. Consequently, globalization also implies welcoming and reshaping one's cultural identity. That is, it needs both stakeholders of the interests at stake. Consequently, globalization also implies welcoming and reshaping one's cultural identity. Hence the reason why in recent years there is a sort of identity claim. (So Settis, 2004, p. 5; Cf. Martelli, 2011; Gattamorta, 2017; Abrosini, 2011; Cortesta, 2005; Benhabib, 2005)

Religion is not only a spiritual value, but also a historical, cultural and belonging. It is true that identity must not be threatened by globalization, but must be valued in it.

But when it comes to religious identity, the situation changes as the individual can recognize himself in it and not the state, since the recognition of the state in a religion means that no one else except the indigenous population can recognize themselves in the state. Having said that, we can believe that collective religious identity is the true victim of globalization and not individual religious identity.

Collective identity is "suppressed" in the name of the principle of religious pluralism and the secular state. On the basis of its own Constitutional and cultural experience, each State identifies itself with a particular form of secularism. It is noted that secularism is presented as an "elastic" principle, as it is influenced not only by the constitutional structure, but also by the culture and history of a country.

\section{Final Considerations}

As regards Italy and even a little of all of Europe, the Catholic religion has had and continues to have an important role in the evolution of national identity, for this region it does not seem possible to ignore that the crucifix today has a multi-semantic value, but this does not exclude that its original message is the religious one, its religious value is undisputed and in eliminable. For this reason, the assumption of him by a secular state appears unjustifiable.

The case examined, that of Mrs. Lautsi, highlights how delicate it is to interpret and implement the principle of the secular nature of the State, since every interpretation is against or for the crucified when it is exposed it seems to contain a part of the truth. The incompetence declared by the Constitutional Court, invested in the question incidentally, has faded the hope of finally resolving the issue.

Even the contradictory pronouncements of the ECHR do not optimize the situation. The Grand Chamber made the cross - representative a man who gave an objective meaning to his death, his sacrifice inspired all of humanity - a symbol unable to transmit and express.

Each symbol carries with it the propaganda or conditioning content, however subliminal, of the consciences. Each symbol has an intrinsic suggestion and influences an emotional value of a negative or positive pole. Otherwise, the behaviour of those who set the flag of an enemy country on fire could not be explained.

It seems relevant for the purposes of guarantees of freedom and state neutrality not to attribute a propaganda or conditioning content to the symbol, even if surreptitiously.

The Grand Chamber, supporting the peculiarity of a passive symbol, seems to want to guide national judges and legislators to put aside any ideological attitude towards the problem of the display of religious symbols in public places.

The intent of the ECHR is to stimulate the contracting states for a more realistic, friendly and non-hostile vision towards religious symbolism. 
Also, deregulation ${ }^{9}$ cannot be a solution from a strictly juridical point of view, a rather nihilistic solution, as it would blur the principles guaranteed in the Constitution. (Ceccanti, 2003)

The State is the guarantor of these principles and must monitor and guarantee in a neutral, secular and non-discriminatory way, so that all citizens can have equal dignity even in the face of the religious phenomenon. This is because freedom of religion, whether positive or negative, together with freedom of conscience must exist in compliance with the principle of equality.

In conclusion, we can believe that there is a lack of Italian jurisprudence in the application of the constitutional principle of the secular state (Cf. Fiorita, 2009).

In light of the principle of secularism, the neutrality of public spaces is the only legally admissible solution. The neutrality of the state not only does not reduce religious freedom, but it reinforces it. Because only neutrality can guarantee freedom of religion, even its negative dimension ${ }^{10}$.

\section{References}

Abet G. (2005). La "laicité à la française" tra passato e futuro (The "laicité à la française" between past and future), Rome, Carocci.

Abrosini M. (2011). Sociologia delle migrazioni (Sociology of migration), il Mulino, Bologna.

Anrò I. (2009). Il crocifisso e la libertà di non credere (The crucifix and the freedom not to believe), in Forum Quad. Cost.

Baldassare P. (2004). Società multiculturale e laicità, (Multicultural society and secularism) in AA.VV., La laicità crocifissa? Il nodo costituzionale dei simboli religiosi nei luoghi pubblici, (The crucified secularism? The constitutional knot of religious symbols in public places).

Bauma Z. (1999) Dentro la globalizzazione. Le conseguenze sulle persone (Inside globalization. The consequences on people), Laterza, Rome - Bari.

Bauman Z. (2008). La solitudine del cittadino globale (The loneliness of the global citizen), Feltrinelli, Milan.

Beck U. (1999). Che cos'è la globalizzazione. Rischi e prospettive della società planetaria (What is globalization. Risks and prospects of the planetary society), Carocci editore, Rome.

Belgiorno De Stefano M. G. (2010). Il crocifisso nelle aule scolastiche in Italia. Una condanna annunciata della Corte Europea dei Diritti Umani (The crucifix in school classrooms in Italy. A conviction announced by the European Court of Human Rights), in www.statoechiese.it.

Benhabib A. R. (2005). La rivendicazione dell'identità culturale. Eguaglianza e diversità nell'era globale (The claim of cultural identity. Equality and diversity in the global era), il Mulino, Bologna.

Bobbio N. (1990). Pluralismo, in Dizionario della politica (Pluralism, in Dictionary of politics), Utet, Turin.

Bourdieu P. (2001). Contre - feux 2. Pour un mouvement social europèen (Contre - feu 2. For a European social movement), Liber, Paris.

\footnotetext{
${ }^{9}$ This solution was chosen by the Bavarian legislator who in article 7, part 3 of the Law on Education and Public Education of 21 June 1983, held that "In consideration of the historical and cultural connotation of Bavaria, in every classroom a crucifix is posted. This expresses the will to achieve the supreme educational purposes of the constitution on the basis of Christian and Western values in harmony with the protection of religious freedom. If the posting of the crucifix is contested by those who have the right to education for serious and understandable religious or ideological reasons, the didactic director seeks an amicable agreement. If the agreement is not reached, he must adopt, after informing the school supervisor, an ad hoc rule (for the individual case) that respects the freedom of religion of the dissenting and brings about a fair reconciliation of the religious and ideological convictions of all the pupils of the class; at the same time, the will of the majority must also be taken into consideration as far as possible. (...)".

${ }^{10}$ From this point of view, we can recall the decision of the Superior Council of the Judiciary, the latter in the Tosti case highlighted that, "even to be able to share the thesis of the purely cultural meaning of the crucifix, the problem of protecting freedom of conscience and pluralism would move from the exclusively religious terrain to the cultural one, but it would not be resolved, since from the previously identified constitutional principles it follows that the public administration cannot choose to privilege an aspect of national tradition and culture, albeit a largely majority one, to to the detriment of other minorities". Thus the Disciplinary Section of the Superior Council of the Judiciary, no. 12 of 2006. We can believe that the decision of the Superior Council of the Judiciary is one of the few in conformity with the principle of the secular state.
} 
Busnelli F. (2009). Riflessioni sul problema del crocifisso nelle scuole (Reflections on the problem of the crucifix in schools), in La nuova giuris, civ. comm.

Cardia C. (2010). Identità religiosa e culturale europea. La questione del crocifisso (European religious and cultural identity. The question of the crucifix), Allemandi, Turi.

Carlassarre L. (2009). Una prevedibile sentenza nel nome della Laicità (A predictable sentence in the name of secularism) in La nuova giuris, civ. comm.

Castells M. (2004). Globalización e Identidad (Globalization and Identity), Institut Europeu de la Mediterránea, Barcelona, DL.

Cavana P. (2012). I simboli religiosi nello spazio pubblico nella recente esperienza europea (Religious symbols in the public space in the recent European experience), in Stato, Chiese e pluralismo confessionale, no. 28, in www.statoechiese.it.

Ceccanti S. (2003). La legge bavarese sul crocefisso (The Bavarian law on the crucifix) in www.forumcostituzionale.it.

Celotto A. (2004). Il simbolo sacro inserito tra gli arredi scolastici può mettere in discussione la laicità dello Stato (The sacred symbol inserted among the school furnishings can question the secularism of the state), in Guida al diritto, 8.

Chessa O. (2006). Laicità come uguale rispetto e considerazione, (Secularism as equal respect and consideration), in www.associazionedeicostituzionalisti.it.

Cimbalo G. (1999). La scuola tra servizio pubblico e principio di sussidiarietà, (The school between public service and the principle of subsidiarity), Giappichelli, Turin.

Clark I. (1997). Globalization and Fragmentation: International relations in the Twentieth Century (Globalization and Fragmentation: International relations in the Twentieth Century), Oxford University Press, Oxford.

Colaianni N. (2004). Prospettive processuali della "questione del crocifisso" (Procedural perspectives of the "question of the crucifix"), in www.associazionedeicostituzionalisti.it.

Colaianni N. (2010). Il crocifisso tra Roma e Strasburgo, in Stato, Chiese e pluralismo confessionale (The crucifix between Rome and Strasbourg, in State, Churches and confessional pluralism), Telematic magazine, in www.statoechiese.it.

Conte R. (2005). Principio di uguaglianza e tutela delle religioni nella giurisprudenza costituzionale (Principle of equality and protection of religions in constitutional jurisprudence), in Questine Giustizia.

Cornia G. A. (2012). Inequality Trend and tjei Determinants in Latin America over 1990-2010, Working Paper No.9.

Cortese F., Mirate S. (2010). La CEDU e il crocifisso: prodromi, motivi e conseguenze di una pronuncia tanto discussa (The ECHR and the crucifix: prodromes, reasons and consequences of a much discussed pronunciation), in Forum Quad. cost.

Cortesta V. (2005). Lo straniero, Pluralismo culturale e immagini dell'Altro nella società globale (The stranger, cultural pluralism and images of the Other in global society), Laterza, Rome-Bari.

D'Elia G. (2012). Il Crocifisso nella aule scolastiche: un paradosso che non resiste all'Europa (The Crucifix in the classroom: a paradox that does not resist Europe) in www.forumcostituzionale.it.

De Oto A. (200o). Presenza del crocifisso o di altri immagini religiose nei seggi elettorali: la difficile affermazione di una "laicità effettiva" (Presence of the crucifix or other religious images in the polling stations: the difficult affirmation of an "effective secularism"), in Quad. dir. pol. eccl., With the note of the Court of Cassation, Criminal Section IV, sentence no. 439 of 2000, in Quad. dir. pol. eccl., 3.

Denaro M. T. (2009). La questione del crocifisso arriva a Strasburgo. La Corte, con un'articolata sentenza, ne vieta l'esposizione nelle aule scolastiche. Le polemiche però, non si sono sopite (The question of the crucifix comes to Strasbourg. The Court, with an articulated ruling, prohibits its display in school classrooms. The controversies, however, have not subsided), in Giust. Amm.

Di Genio G. (2009). Laicità europea e struttura pluralista dell'ordinamento (European secularism and pluralist structure of the legal order) in Forum Quad. Cost.

Dickman R. (2010). Il giudice e il crocifisso (The judge and the crucifix) in www.federalismi.it.

Enciclopedia Britannica, in https://www.britannica.com

Feng W. (2011). The end of 'Growth with equity"? Economic Growth and income inequality in East Asia, Asia pacific Issues.

Ferrari S. (2001). La libertà religiosa nell'età della globalizzazione del postmoderno. La questione del proselitismo (Religious freedom in the age of postmodern globalization. The question of proselytism), in Coscienza $e$ libertà, 35 .

Fiorillo V. (2010). Il crocefisso a Strasburgo: l'Italia non è la Francia (The crucifix in Strasbourg: Italy is not France), in Quad. cost. 
Fiorita N. (2005). Se il crocefisso afferma e conferma la laicità dello Stato: paradossi, incongruenze e sconfinamenti di una sentenza del Tar Veneto (If the crucifix affirms and confirms the secular nature of the state: paradoxes, inconsistencies and encroachments of a sentence of the Veneto TAR), in Foro it., III.

Fiorita N. (2009). Se Terni non è Valladolid (If Terni is not Valladolid), in www.forumcostituzionale.it.

Fusaro C. (2004). Pluralismo e laicità. Lo Stato non può ridurre la fede a cultura, né costruire sul fatto religioso identità partigiane (Pluralism and secularism. The State cannot reduce faith to culture, nor build partisan identities on the religious fact), in AA.VV., La laicità crocifissa? Il nodo costituzionale dei simboli religiosi nei luoghi pubblici (The crucified secularism? The constitutional knot of religious symbols in public places), Atti del Seminario, Ferrara 28 may 2004, Giappichelli, Turin.

Gallino L. (2003). Globalizzazione e disuguaglianze (Globalization and inequalities), Laterza, Rome-Bari.

Gattamorta L. (2006). Teorie del simbolo. Studio sulla sociologia fenomenologica (Symbol theories. Phenomenological sociology study), Franco Angeli, Milan.

Gattamorta L. (2017). La natura plurale e i processi della globalizzazione culturale (The plural nature and processes of cultural globalization), in S. Belardinelli, P. Terenzi, (editet by), Le dinamiche culturali della globalizzazione, Rubbettino, Saveria Mannelli.

Giddens A. (200o). Il mondo che cambia. Come la globalizzazione ridisegna la nostra vita (The changing world. How globalization reshapes our life), Il Mulino, Bologna.

Grossi P. (2008). Il diritto costituzionale tra principi di libertà e istituzioni (Constitutional law between principles of freedom and institutions), Cedam, Padova, 2008.

Hirst P., Thompson G. (1999). Globalizationin question: the international economy and the possibilities of governance, Polity Press, Maldes, cop.

Hobbes TH. (2004). Leviatano o la materia, la forma e il potere di uno Stato ecclesiastico e civile (Leviathan or the matter, form and power of an ecclesiastical and civil state), (editet by) A. Pecchi, Laterza, Rome- Bari.

Huntington S. P. (1998). La terza ondata. I processi di democratizzazione alla fine del XX secolo (The third wave. The democratization processes at the end of the twentieth century), Il Mulino, Bologna.

Huntington S. P. (200o). Lo scontro delle civiltà e il nuovo ordine globale, Garzanti, Milano. Original title, The Clash of Civilizations and the Remaking of World Order, Simon \& Schuster, New York, 1996.

Huntington S. P., Berger P., Peter L. (2002). Many Globalizations: cultural diversity in the contemporary world, Oxford University Press, Oxford.

Jemolo C. (1961). I problemi pratici della libertà (The practical problems of freedom), Giuffre, Milan.

Kermiche S. (2009). L'interdiction de crucifix dans les écoles publiques: une décision contraire au principe de laïcité italien? (The ban on crucifixes in public schools: a decision contrary to the principle of Italian secularism?) in www.federalismi.it, no. 22.

Laudani F. (2010). La questione del crocifisso all'indomani della sentenza della Corte EDU e del Trattato di Lisbona (The question of the crucifix following the ruling of the ECHR and the Lisbon Treaty), in www. forumcostituzionale.it.

Luciani M. (2008). La problematica laicità italiana (The problematic Italian secularism), in Dem. Dir., no. 2.

Majorana G. (2004). La questione del crocifisso alla luce della dimensione promozionale della libertà religiosa (The question of the crucifix in the light of the promotional dimension of religious freedom) in AA.VV., La laicità crocifissa? Il nodo costituzionale dei simboli religiosi nei luoghi pubblici, (The crucified secularism? The constitutional knot of religious symbols in public places), Atti del Seminario, Ferrara 28 may 2004, Giappichelli, Turin.

Majorana G. (2004). La questione del crocifisso alla luce della dimensione promozionale della libertà religiosa (The question of the crucifix in the light of the promotional dimension of religious freedom), in AA.VV., La laicità crocifissa? Il nodo costituzionale dei simboli religiosi nei luoghi pubblici, (The crucified secularism? The constitutional knot of religious symbols in public places), Atti del Seminario, Ferrara 28 may 2004, Giappichelli, Turin.

Martelli L. (2011). Sociologia della globalizzazione (Sociology of globalization), Einaudi, Turin.

Martinelli C. (2007). Laicità come neutralità, in Stato, Chiese e pluralismo confessionale (Secularism as neutrality, in the State, Churches and confessional pluralism), Rivista telematica, in www.statoechiese.it .

Matteucci N. (1996). Pluralismo (Pluralism), in Enciclopedia delle scienze sociali, VI, Enc. Giur. Trecc., Rome.

Olinto P., Saavedra J. (2012). An overview of global inequality trends, World Bank, Inequality in focus.

Olivetti M. (2001). Crocifisso nelle scuole pubbliche: considerazioni non politicallycorrect (Crucifix in public schools: non-politically correct considerations), in Forum di Quaderni Costituzionali, 4.

Ricciradi M. (2020). Liberali egualitari, L'utopia ragioneveole di una golbalizzazione giusta (Egalitarian Liberals, The Reasonable Utopia of a Just Golbalization), Linkiesta, 2 June.

Rimoli F. (1995). voice Laicità (voice Secularism), in Enc. Giur., XVIII, Treccani, Rome. 
Risset J. (2005). Sulla nozione di laicità. A proposito della "legge sul foulard" (On the notion of secularism. About the "foulard law"), in Parole chiave/ Laicità, 33.

Riviera A. M. (2005). L'interdetto del velo: antropologia di una contesa pubblica (The interdict of the veil: anthropology of a public dispute), in Parole chiave/ Laicità, 33.

Ruggiu I. (2010). Perché neanche l'argomento culturale” giustifica la presenza del crocifisso negli spazi pubblici (Because not even the "cultural argument" justifies the presence of the crucifix in public spaces), in Forum Quad. Cost.

Rusconi G. E. (27 october 2003), Stampa.

Semplici S. (2005). Dopo il Califfo: La Turchia, il modello francese e il 'ritorno in pubblico' della religione (After the Caliph: Turkey, the French model and the 'public return' of religion), in Parole chiave/ laicità.

Settis S. (2004). Futuro del classico (Future of the classic), Einaudi, Turin.

Talamanca A. (1997). Libertà della scuola, libertà nella scuola, (Freedom of the school, freedom in the school), Cedam, Padua.

Tokrri R. (2014). Jurisprudenca kontradiktore e GJEDNJ (Contradictory jurisprudence of the ECHR), in Globale Challenge, no. 10. ISSN 2227-8540 ISSN 2312-5748 (Online).

Tokrri R. (2015). From tolerance to the secular State in Italy, in Academicus Journal of Interdisciplinary Studies, ISSN 2281-4612 (ON LINE) ISSN 2281-3993 (PRINT). Academicus-MMXV-11-051-062.pdf.

Tokrri R. (2017). The religious roots of seculare state (From the Albertino Statute to the present), in Illyrius International Review, 2225-2894, Rome.

Tokrri R. (2019). The feedom of consience in the Italian Constitution betweenreligion and atheism, enclosed in the deepest part of human dignity, in Illyrius International Review, ISSN 2225-2894, no.13, II, pp. 51-80.

Tokrri R. (2020). Pluralist Albania-Religios Tolerance or Paceful Coedxistence European Jourlan of Interdisciplinary Studies, in European Center for Science and Research, Vol. 6, May-Aug., ISSN 2411-4138.

Tordov T. (1991). Teoria del simbolo (Theory of symbol), Garzanti, Milan.

Valentino V. (2014). La sentenza sul caso S. A. S. c. Francia della Corte Europea dei diritti dell'uomo: principio di laicità e divieto assoluto di coprirsi il volto in pubblico, (The sentence on the case of S. A. S. c. France of the European Court of Human Rights: principle of secularism and absolute prohibition of covering one's face in public), in Osservatorio costituzionale.

Vari F. (2012). Note su religione e sfera pubblica tra Costituzione italiana e Convenzione europea "dei diritti dell'uomo" (Notes on religion and the public sphere between the Italian Constitution and the European Convention "on human rights"), in Stato, Chiese e pluralismo confessionale, www.statoechiese.it.

Ventura M. (2012). Le virtù della giurisdizione europea sui conflitti religiosi, in Diritto e religione in Europa, Rapporto sulla giurisprudenza della Corte europea dei diritti dell'uomo in materia di libertà di religione, (The virtues of European jurisdiction on religious conflicts, in Law and Religion in Europe, Report on the jurisprudence of the European Court of Human Rights in matters of freedom of religion), (edited by) R. Mazzola, Il Mulino, Bologna.

Veronesi P. (2005). L'ordinanza n. 389/2004 della Corte costituzionale e il suo seguito: la logica giuridica "messa in croce" (Ordinance no. 389/2004 of the Constitutional Court and its follow-up: the juridical logic "put on the cross"), in Studium Iuris.

Zagrebelsky G. (2010). Scambiarsi la veste. Stato e Chiesa al governo dell'uomo, (Swap clothes. State and Church under the rule of man), Laterza, Rome.

Zagrebelsky G. (2012). Simboli al potere. Politica, fiducia, speranza (Symbols in power. Politics, trust, hope), Einaudi, Turin.

Zannotti L. (1990). Il crocifisso nelle aule scolastiche (The crucifix in the classroom), in Il Diritto Ecclesiastico, vol 2. 